\title{
Anaerobic co-digestion of tannery solid waste: Optimum leather fleshing waste loading
}

\author{
Tabakhane katı atıklarının anaerobik birlikte çürütülmesi: Optimum \\ etleme atığı yükü
}

\author{
Alper BAYRAKDAR ${ }^{1+}$ (D) \\ ${ }^{1}$ Department of Environmental Engineering, Engineering Faculty, Izmir Institute of Technology, Izmir, Turkey \\ alperbayrakdar@gmail.com
}

\begin{abstract}
In this study, loading of optimum leather fleshings was investigated with four identical batch reactors with different fleshings and treatment sludge ratios $(0: 1,0.25: 1,0.35: 1,0.50: 1)$ to contribute to the state of art of the biogas production from tannery solid wastes. Results showed that lipids-containing leather fleshings boosted the methane production potential. However, H2S inhibition and volatile fatty acids accumulation were the main concern in the anaerobic digestion of these wastes. The modified Gompertz model was applied to the batch tests data to determine the kinetic constants of anaerobic digestion of tannery solid wastes. It was calculated with the model outputs that the ultimate methane production potential and maximum methane production rate in reactors having mixing ratio of 0.35:1 and 0.5:1 (dry basis) were highly similar. 0.35 was found to be an optimum leather fleshing and treatment sludge ratio with a 54\% more methane production potential than that of control reactor in this study.
\end{abstract}

Keywords: Anaerobic digestion, Leather fleshings, Biogas, Lipids, Hydrogen sulfide.

\section{Introduction}

Tanning industry is one of the oldest sectors in the history of human beings. Because of the severe environmental problems related to leather production process and the increasing labor prices, the production sector has been declining in developed regions and become widespread mostly in the far east countries such as China, Vietnam, Endonesia [1],[2].

Leather making process is basically divided into three steps: pre-tanning including soaking, unhairing and liming, fleshing, splitting, deliming, bating and pickling; tanning process; and the finishing process [1]. Substantial amount of solid waste is generated during pre-tanning operations such as skin trimmings, keratin wastes and fleshings, which consist of mainly protein and lipids [3]. The fleshing operation is performed in order to remove flesh and fats from the skin so that the rapid skin degradation can be prevented and chemicals used in the subsequent steps can easily penetrate to the raw skin [4]. Hence, fleshing wastes are the major portion of the solid waste caused by tanning industry [5]. Besides, high amount of treatment sludge is revealed due to treatment of leather industry's wastewater. As a result of the production of

\section{Öz}

Tabakhane katı atıklarından biyogaz üretimi üzerine literatüre katkı sağlamak amacıyla yürütülen bu çalısmada deri etleme atığı yükünün anaerobik biyogaz üretimine etkisi ve optimum deri etleme atığı yükü, farklı etleme atığı ve arıtma camuru karısım oranlarıla (0:1, 0.25:1, 0.35:1, 0.50:1) kesikli olarak işletilen dört eşdeğer anaerobik reaktör ile incelenmiștir. Elde edilen sonuçlar, lipit içeren atıkların metan üretim potansiyelini arttırdığını göstermiștir. Ancak, H2S inhibisyonu ve uçucu yağ asitlerinin birikimi bu atıkların anaerobik olarak çürütülmesinde dikkat edilmesi gereken önemli hususlar olarak görülmüstür. Kesikli deneyler ile elde edilen verilere Gompertz modeli uygulanarak bu atıkların anaerobik olarak çürütülmesinde kinetik katsayılar belirlenmiștir. 0.35: 1 ve 0.5: 1 (kuru bazda) karışım oranı ile işletilen reaktörlerin nihai metan üretim potansiyelleri ve metan üretim hızı değerlerinin oldukça benzer olduğu model çıktıları ile hesaplanmıştır Çalışmada, 0.35:1 karışım oranı ile işletilen reaktörün hiç etleme atığı ilave edilmemis kontrol reaktörüne göre \%54 daha fazla metan üretim potansiyeline sahip olduğu ve bu karışım oranının optimum etleme atığ ve arıtma çamuru oranı olduğu gözlenmiștir.

Anahtar kelimeler: Anaerobik çürütme, Etleme atığı, Biyogaz, Lipit, Hidrojen sulfur.

\footnotetext{
${ }^{*}$ Corresponding author/Yazışılan Yazar
}

one ton of raw hide, up to $250 \mathrm{~kg}$ of fleshings and $200 \mathrm{~kg}$ of treatment sludge are generated [4],[6].

Because of the high organic and inorganic content, tanning industry solid wastes may cause severe environmental problems unless managed properly [7]. Substantial amount of research has been carried out to develop methods for the recovery and utilization of fleshings such as proteolic enzymes [8] and biodiesel [9] production, fat and protein recovery and glue production [10]. However, they are generally complex processes requiring high amount of energy, chemical and time [10]. Landfilling is the most widely used way for the management of leather industry solid wastes since recovery opportunities are very limited and not feasible [5],[10],[11]. Nevertheless, it is well known that landfilling of those wastes is not a good option from the environmental point of view [12],[13].

In response to increasing energy demand and new strict environmental regulations and policies, anaerobic digestion has become an attractive solution in the management of tannery solid wastes [7],[14]. In addition to energy recovery and production of lower amount of sludge, which has to be managed, biologically stabilized nutrient-rich digestate can be 
used as an organic fertilizer in the agricultural activities [11],[15].

Several studies regarding anaerobic digestion of leather solid wastes agree on process feasibility. However, possible operational problems such as unbalanced $\mathrm{C} / \mathrm{N}$ ratio, inhibition of ammonia, long chain fatty acid and sulfide have also been reported [6],[14],[16].

The present work is aimed to increase knowledge on the application of anaerobic co-digestion of fleshings, and treatment sludge, which is caused by tannery wastewater treatment activities, by investigating optimum treatment sludge and fleshings mixing ratio with batch bio-methane potential tests.

\section{Material and methods}

\subsection{Substrates and Inoculum}

Tannery fleshings and dewatered treatment sludge (primary and secondary sludge) were taken from the leather industrial zone located in Turkey. Fleshings had been ground to $5 \mathrm{~mm}$ diameter using a meat mincer and homogenized before being characterized. Inoculum (active methanogenic sludge) used in the batch tests was collected from the existing anaerobic digester of leather industrial zone operated with treatment sludge of leather industry wastewater. Characterization of leather fleshings, treatment sludge and inoculum were performed just after arriving at our laboratory.

\subsection{Experimental set-up and operational conditions}

Bio-methane potential (BMP) experiments were carried out to determine the optimum fleshings and treatment sludge mixing ratio for anaerobic digestion process. Four identical glass 1100 ml-total and $800 \mathrm{ml}$-active volume of batch reactors (R1-R4) were operated for 72 days. BMP tests were performed under mesophilic conditions $\left(36 \pm 1^{\circ} \mathrm{C}\right)$ using temperature-controlled cabinet (WTW, TS606/4-i). Reactors were placed onto an orbital shaker (Biosan, PSU-20i) and continuously stirred during the study. Total solid (TS) concentration of each reactor was adjusted to $8 \%$, which is the same with the existing digester solid content (dissolved solid was excluded). R1 was operated as a control reactor in which no fleshings were added. Fleshings to sludge ratio of R2, R3 and R4 were adjusted to $0.25: 1,0.35: 1$ and $0.5: 1$ on TS basis, respectively (Table 1 ).

Table 1. Operational conditions.

\begin{tabular}{ccccc}
\hline & \multicolumn{4}{c}{ Reactor \# } \\
\cline { 2 - 5 } Parameters & R1 & R2 & R3 & R4 \\
\hline Fleshings, gr & - & 63 & 82 & 105 \\
Sludge, gr & 256 & 200 & 190 & 107 \\
Inoculum, gr & \multicolumn{4}{c}{90} \\
$\begin{array}{c}\text { TSa , \% } \\
\text { VS, \% }\end{array}$ & 5.08 & 5.25 & 5.47 & 5.55 \\
$\begin{array}{c}\text { Fleshings: Sludge } \\
\quad \text { Ratio } \\
\text { (TS basis) }\end{array}$ & 0 & 0.25 & 0.35 & 0.50 \\
$\begin{array}{l}\text { *: Control reactor, TS: Total solid/Dry matter, a: dissolved solid values were } \\
\text { excluded, VS: volatile solid }\end{array}$ & & &
\end{tabular}

After adding required amount of fleshings and sludge, $\mathrm{pH}$ of R2, $\mathrm{R} 3$ and R4 were adjusted to 7.6-7.8 with $1 \mathrm{~N} \mathrm{HCl}$ and reactors were flushed with nitrogen gas for $10 \mathrm{~min}$ to maintain the anaerobic conditions before initializing the experiments. Aluminum foil gas bags were connected to reactors to collect biogas produced (Figure 1).

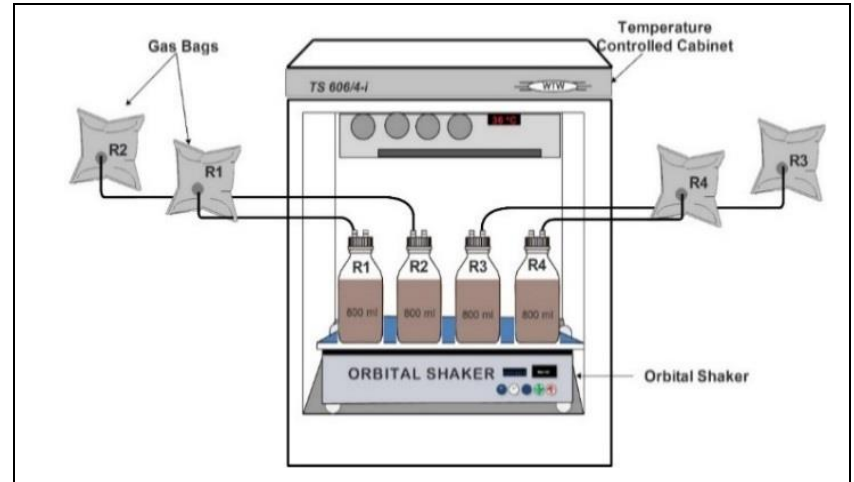

Figure 1. Experimental set-up

\subsection{Analytical techniques}

Total solid (TS, APHA-2540B), volatile solid (VS, APHA-2540E), chemical oxygen demand (COD, APHA-5220D) and total kjeldahl nitrogen (TKN, APHA-4500 $\mathrm{N}_{\text {org }} \mathrm{C}$ ) analyses were performed according to standard methods [17]. Dissolved solid was determined by using a conductivity meter (Eutech cyberscan PCD 6500, Singapore). Total ammonia nitrogen (TAN) was measured with the nesslerization method (HACH8038) by using a spectrophotometer (WTW photoLab 6100, Germany). Volatile fatty acids were determined by using a gas chromatograph (GC) (Shimadzu GC-2014, Japan) according to method described by Bayrakdar et al. [18]. pH was analyzed using a pH meter (WTW 3310, Germany). Total sulfide was analyzed according to a spectrophotometric method described by Cord-Ruwisch [19] using WTW photoLab 6100 (Germany) spectrophotometer. Daily biogas production was measured with weight-type gasometer and biogas composition $\mathrm{CH}_{4}, \mathrm{CO}_{2}$ and $\mathrm{H}_{2} \mathrm{~S}$ ) was determined using GC equipped with thermal conductivity detector according to method reported by Reddy et al. [20].

\subsection{Data analyses}

The kinetic constants which are maximum methane production rate $(\mathrm{Rm}: \mathrm{L} / \mathrm{kgVS} / \mathrm{d})$, lag-phase time $(\lambda$ : day) and methane production potential (P: L/kgVS) were estimated for each BMP test with modified Gompertz model (Equation 1) using Microsoft Excel 2016 Solver tool.

$$
M=P \times \exp \left\{-\exp \left[\frac{R_{m} \times e}{P}(\lambda-t)+1\right]\right\}
$$

Where $\mathrm{M}$ is the cumulative methane production (L) at time $\mathrm{t}$ (day) and e is the Euler's number (2.718).

\section{Results and discussions}

\subsection{Characterization of waste and inoculum}

The characterization of leather fleshings, treatment sludge and inoculum were given in Table 2. In addition to lipids and protein, tannery solid wastes contain residual chemicals such as lime and sulfide, which are used in beam house operations for the purpose of hair removal [16]. Hence, the $\mathrm{pH}$ of fleshings was more than 12 like reported also by Thangamani et al. [16].

Since this $\mathrm{pH}$ value will adversely affect the biogas production, $\mathrm{pH}$ of the fleshings-added reactors was decreased with $1 \mathrm{~N} \mathrm{HCl}$ before initializing the study. 
Table 2. Characteristics of Fleshings, Treatment Sludge and Inoculum.

\begin{tabular}{lccc}
\hline Parameters & Fleshings & $\begin{array}{c}\text { Treatment } \\
\text { Sludge }\end{array}$ & Inoculum \\
\hline $\mathrm{pH}$ & $12.5 \pm 0.5$ & $7.91 \pm 0.2$ & $7.8 \pm 1$ \\
TS, \% & $20.6 \pm 0.9$ & $23.63 \pm 0.38$ & $5 \pm 0.5$ \\
VS, \% & $16.1 \pm 0.65$ & $15.35 \pm 0.22$ & $2.5 \pm 0.3$ \\
TSS, \% & $18.7 \pm 0.91$ & $23.17 \pm 0.40$ & $2.86 \pm 0.01$ \\
Total COD, g/kg & $221 \pm 6.5$ & $252 \pm 21$ & $42 \pm 2$ \\
TKN, g/kg & $13.61 \pm 1$ & $11.14 \pm 0.51$ & $1.05 \pm 0.02$ \\
Total Sulfide, & $305 \pm 8.8$ & $120 \pm 20$ & $93.3 \pm 5.34$ \\
mg/kg & & &
\end{tabular}

TS: Total solid, VS: Volatile solid, TSS: Total suspended solid, COD: Chemical oxygen demand, TKN: Total kjeldahl nitrogen.

\subsection{Effect of mixing ratio on bio-methane potential}

Bio-methane potential tests lasted for 72 days. Biogas amount and the compositions were analyzed and recorded daily. The methane yield profiles of batch experiments were given in Figure 2.

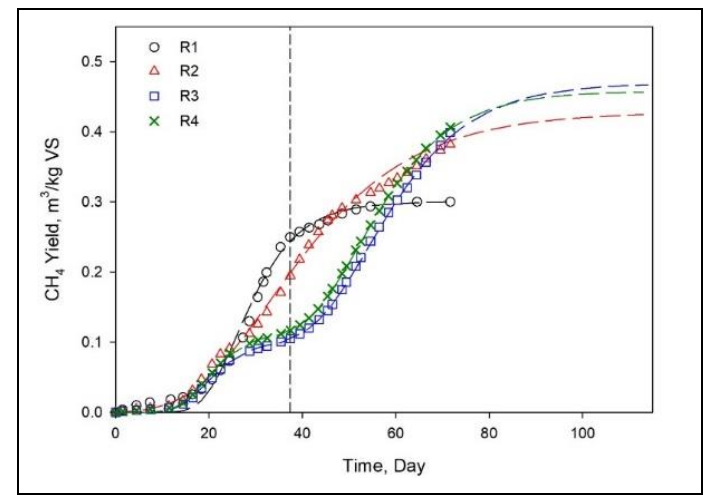

Figure 2. Methane yield profiles of BMP tests

It can clearly be seen from Figure 2 that no significant methane production was observed for almost 15 days of operation for all BPM tests because of likely high concentration of $\mathrm{H}_{2} \mathrm{~S}$ (Figure 3). Methane production rate increased when $\mathrm{H}_{2} \mathrm{~S}$ concentration in biogas decreased below 2\% (Fig.3). The sulfide is one of the inhibitory compounds for anaerobic digesters and causes an inhibition at a wide-range of 100-800 $\mathrm{mg} / \mathrm{L}$ total sulfide depending on $\mathrm{pH}$, temperature and existence of other inhibitory compounds like ammonia. [21,22]. Bayrakdar et al. [18] reported that VFA accumulation was observed when the $\mathrm{H}_{2} \mathrm{~S}$ concentration exceeded $1 \%$ in biogas and a similar result was also reported by Sürmeli et al. [22].

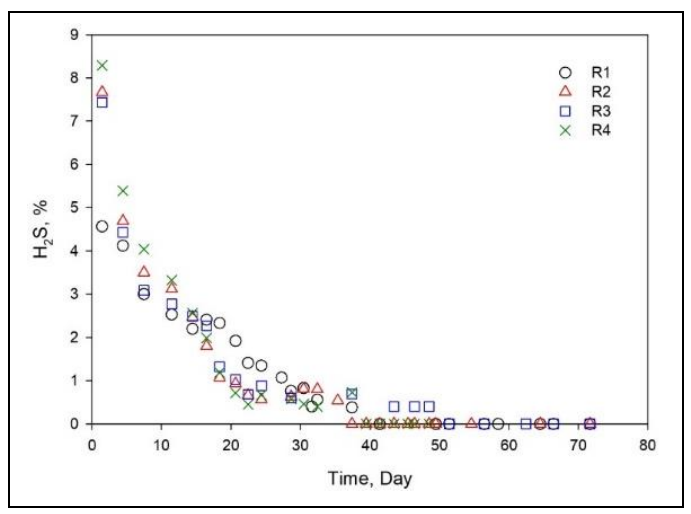

Figure $3 . \mathrm{H}_{2} \mathrm{~S}$ concentrations in biogas.
Total methane productions were $11.7 \mathrm{~L}, 15.6 \mathrm{~L}, 16.7 \mathrm{~L}$ and 17.2 $\mathrm{L}$ and methane yields were $0.3,0.38,0.39$ and $0.40 \mathrm{~m}^{3} \mathrm{CH}_{4} / \mathrm{kgVS}$ for R1, R2, R3 and R4, respectively, in 72 days. However, methane production rates of $\mathrm{R} 3$ and $\mathrm{R} 4$ were decreased seriously compare to R1 and R2, after day 28 (Fig.2 and 4). To find out the reason of declining methane production rate, samples were taken from the supernatant of all reactors on day 30 and $\mathrm{pH}$, TAN and VFAs analyses were performed. Results were given in Table 3 .

Table 3. Results of analyses performed on day 30 .

\begin{tabular}{cccc}
\hline Reactor \# & $\mathrm{pH}$ & $\begin{array}{c}\text { TAN, } \\
\mathrm{mg} / \mathrm{L}\end{array}$ & $\begin{array}{c}\text { Total VFAs, } \\
\mathrm{mgCOD} / \mathrm{L}\end{array}$ \\
\hline $\mathrm{R} 1$ & 7.55 & 1330 & 3.73 \\
$\mathrm{R} 2$ & 7.45 & 2100 & 7.21 \\
$\mathrm{R} 3$ & 7.6 & 2593 & 9.14 \\
$\mathrm{R} 4$ & 7.7 & 2700 & 9.83 \\
\hline
\end{tabular}

According to results, TAN and pH of R3 and R4 were not at the inhibitory levels but a serious VFAs accumulation were observed in both reactors. During the anaerobic digestion, lipids are first hydrolyzed to long chain fatty acids and glycerol, then long chain fatty acids are further degraded to volatile fatty acids and may cause a VFAs accumulation [23,24]. It is known that increasing VFA concentrations results in system inhibition [25]. Over $9 \mathrm{~g} / \mathrm{L}$ of total VFA in COD equivalent caused very likely an inhibition for methanogens. Besides, the shock load of long-chain fatty acids can stop methanogenic activity for longer periods was reported by Angelidaki et al. [23]. It was also reported in the same study that this problem could be overcome after a long adaptation period. To rebuild the methanogenic activity, 90 gr of active inoculum was added to R3 and R4 on day 37 shown with dashed line in Figure 2 and Figure 4. With the addition of inoculum, an obvious increase in methane production rates of R3 and R4 was observed (Figure 4).

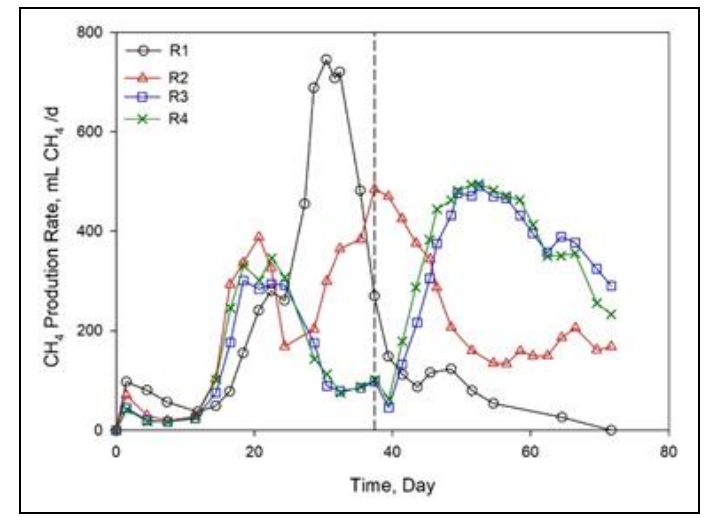

Figure 4. Daily methane production rates.

At the end of the study, 33\%, $42 \%$ and $46 \%$ more methane gas were generated in R2, R3 and R4, respectively, than that of R1. Even though the biogas production in R1 in which no fleshings were added was completed on day 55, fleshings-added reactors continued to produce methane because biogas production potential of lipids higher than that of carbohydrates and proteins [26]. In addition to biogas production potential, methane content of the lipids is higher than those [11].

In the present study, the average methane content of fleshingsadded reactors was $75 \pm 1 \%$ and this shows that the fleshings is a potential substrate for anaerobic digesters in terms of energy generation. The study was stopped on day 72 although 
fleshings-added reactors were still producing methane. Residual total VFA, which are over $3000 \mathrm{mgCOD} / \mathrm{L}$, at the end of the experiment also promote this (Table 5). To determine the ultimate methane production potential and the maximum methane production rate Gompertz model was applied. The model was perfectly fit to the actual data with a correlation of over $99 \%$. The model outputs were summarized in Table 4 .

Table 4. Gompertz model outputs.

\begin{tabular}{cccc}
\hline Reactor \# & $\lambda$, day & $\mathrm{P}, \mathrm{L} / \mathrm{kgVS}$ & $\mathrm{Rm}, \mathrm{L} / \mathrm{kgVS} / \mathrm{d}$ \\
\hline $\mathrm{R} 1$ & 14 & 306 & 13.92 \\
$\mathrm{R} 2$ & 15 & 418.5 & 9.09 \\
$\mathrm{R} 3$ & 13 & 470 & 11.34 \\
$\mathrm{R} 4$ & 13 & 463 & 11.66 \\
\hline
\end{tabular}

$\lambda$ : Lag phase, P: Methane production potential, Rm: maximum methane production rate.

Methane production completed in R1 in a shorter time with a maximum methane production rate of $13.92 \mathrm{~L} / \mathrm{kgVS}$, compared to fleshings-added rectors, due to likely the slow hydrolysis rate of lipids [27]. However, methane production potential of R3 was 1.5 times higher than R1. According to model outputs, there is no significant difference between R3 and R4 in terms of methane production potential and maximum methane production rate (Table 4). Hence, it can be proposed that fleshing to sludge ratio of 0.35 is an optimum ratio for the anaerobic co-digestion of fleshings and treatment sludge.

$\mathrm{pH}, \mathrm{TS}, \mathrm{VS}$ and VFAs analyses were performed from samples taken at the end of the study. Results were given in Table 5 . According to the results of the final analyses, TS and VS removal efficiency of R1, R2, R3 and R4 were 35\%, 42\%, 43\%, 40 and $42 \%, 43 \%$, 48\%, 43\%, respectively. Similar results were also reported by Basak et al. [28]. According to results, 0.35 was determined to be an optimum Fleshings/Sludge mixing ratio for the anaerobic co-digestion of tannery solid wastes. With an almost $50 \%$ of organic matter degradation efficiency and 470 $\mathrm{L} / \mathrm{kgVS}$ methane potential, anaerobic co-digestion of tannery solid wastes is observed to be an environmentally friendly and energy-generating alternative for the management of these type of wastes.

Table 5. Characterization after Anaerobic Digestion

\begin{tabular}{ccccc}
\hline Reactor \# & $\mathrm{pH}$ & $\mathrm{TS}, \%$ & $\mathrm{VS}, \%$ & Total VFA, mgCOD/L \\
\hline R1 & 7.55 & 5.17 & 2.94 & 500 \\
R2 & 7.67 & 4.65 & 3.03 & 3201 \\
R3 & 7.76 & 4.56 & 2.89 & 3099 \\
R4 & 7.84 & 4.83 & 3.10 & 3647 \\
\hline
\end{tabular}

\section{Conclusions}

In this study, different treatment sludge and leather fleshings ratios were investigated to determine the optimum fleshings amount to be loaded to an anaerobic digester. Results showed that lipids containing leather fleshings boosted the methane production. Additionally, its methane content makes the anaerobic digestion process feasible. However, to prevent longchain fatty acid and VFAs accumulation, shock loads must be avoided. Besides, some pretreatments like rinsing of leather fleshings might be needed to eliminate $\mathrm{H}_{2} \mathrm{~S}$ inhibition problem. $47 \%$ more methane gas was produced than that of control reactor in 72 days when the fleshings to sludge ratio of feed mixture was $0.35: 1$ on TS basis. According to Gompertz model, the ultimate methane production potential and maximum methane production rate of R3 and R4 were highly similar and methane potential of R3 was 54\% more than that of control reactor (R1). It is concluded that optimum leather fleshing to treatment sludge ratio is $0.35: 1$.

\section{References}

[1] Thanikaivelan P, Rao JR, Nair BU, Ramasami T. "Recent trends in leather making: Processes, problems, and pathways". Critical Reviews in Environmental Science and Technology, 35(1), 37-79, 2005.

[2] Çalışma ve Șehircilik Bakanlığı. "Sektörel Atık Klavuzları: Deri Sektörü". Ankara, Türkiye, 2016.

[3] Schramm W. "New findings on the generation of waste and emissions, and a modified cleaner production assessment approach - Illustrated by leather production". Journal of Cleaner Production, 5(4), 291-300, 1997.

[4] Sundar VJ, Gnanamani A, Muralidharan C, Chandrababu NK, Mandal AB. "Recovery and utilization of proteinous wastes of leather making: A review". Reviews in Environmental Science and Biotechnology, 10(2), 151-163, 2011.

[5] Agustini CB, Spier F, da Costa M, Gutterres M. "Biogas production for anaerobic co-digestion of tannery solid wastes under presence and absence of the tanning agent". Resources, Conservation and Recycling, 130, 51-59, 2018.

[6] Sri Bala Kameswari K, Kalyanaraman C, Porselvam S, Thanasekaran K. "Optimization of inoculum to substrate ratio for bio-energy generation in co-digestion of tannery solid wastes". Clean Technologies and Environmental Policy, 14(2), 241-250, 2012.

[7] Dhayalan K, Fathima NN, Gnanamani A, Rao JR, Nair BU, Ramasami T. "Biodegradability of leathers through anaerobic pathway". Waste Management, 27(6), 760-767, 2007.

[8] Šánek L, Pecha J, Kolomazník K, Bařinová M. “Biodiesel production from tannery fleshings: Feedstock pretreatment and process modeling". Fuel, 148, 16-24, 2015.

[9] Colak S, Zengin G, Özgünay H, Sari Ö, Sarikahya H, Yüceer L. "Utilization of leather industry pre-fleshings in biodiesel production". Journal of the American Leather Chemists Association, 100(4), 137-141, 2005.

[10] Polizzi C, Alatriste-Mondragón F, Munz G. "The role of organic load and ammonia inhibition in anaerobic digestion of tannery fleshing". Water Resources and Industry, 19, 25-34, 2018.

[11] Berardino S Di, Martinho A. "Co-digestion of tanning residues and sludge". 12th IWA Sludge Conference-Sustainable Management of Water \& Wastewater Sludge, Harbin, China, 8-10 August 2009.

[12] Ravindranath E, Gopalakrishnan AN. "Enhancement of biomethanization by pretreatment of limed fleshings from tanneries". Journal of Scientific and Industrial Research, 69(9), 711-716, 2010.

[13] Ramyar R, Zarghami E, Bryant M. "Spatio-temporal planning of urban neighborhoods in the context of global climate change: Lessons for urban form design in Tehran, Iran". Sustainable Cities and Society, 51, 101554, 2019.

[14] Priebe GPS, Kipper E, Gusmão AL, Marcilio NR, Gutterres M. "Anaerobic digestion of chrome-tanned leather waste for biogas production". Journal of Cleaner Production, 129, 410-416, 2016. 
[15] Akyol Ç, Demirel B, Onay TT. "Recovery of methane from tannery sludge: the effect of inoculum to substrate ratio and solids content". Journal of Material Cycles and Waste Management, 17(4), 808-815, 2015.

[16] Thangamani A, Rajakumar S, Ramanujam RA. "Anaerobic co-digestion of hazardous tannery solid waste and primary sludge: Biodegradation kinetics and metabolite analysis". Clean Technologies and Environmental Policy, 12(5), 517-524, 2010.

[17] American Water Works Association and Water Environment Federation. "Standard methods for the examination of water and wastewater". Washington, DC, USA, 2012.

[18] Bayrakdar A, Sürmeli RÖ, Çalli B. “Dry anaerobic digestion of chicken manure coupled with membrane separation of ammonia". Bioresource Technology, 244, 816-823, 2017.

[19] Cord-Ruwisch R. "A quick method for the determination of dissolved and precipitated sulfides in cultures of sulfatereducing bacteria". Journal of Microbiological Methods, 4(1), 33-36, 1985.

[20] Reddy KS, Aravindhan S, Mallick TK. "Investigation of performance and emission characteristics of a biogas fuelled electric generator integrated with solar concentrated photovoltaic system". Renewable Energy, 92, 233-243, 2016.

[21] Parkin GF, Lynch NA, Kuo WC, Vankeuren EL, Bhattacharya SK. "Interaction between sulfate reducers and methanogens fed acetate and propionate". Research Journal of the Water Pollution Control Federation, 62(6), 780-788, 1990.
[22] Sürmeli RÖ, Bayrakdar A, Molaey R, Çalli B. "Synergistic effect of sulfide and ammonia on anaerobic digestion of chicken manure". Waste and Biomass Valorization, 10(3), 609-615, 2019.

[23] Angelidaki I, Ahring BK. "Effects of free long-chain fatty acids on thermophilic anaerobic digestion". Appl Microbiol Biotechnol, 37, 808-812, 1992.

[24] Cirne DG, Paloumet X, Björnsson L, Alves MM, Mattiasson B. "Anaerobic digestion of lipid-rich waste-Effects of lipid concentration". Renewable Energy, 32(6), 965-975, 2007.

[25] Siegert I, Banks C. "The effect of volatile fatty acid additions on the anaerobic digestion of cellulose and glucose in batch reactors". Process Biochemistry, 40(11), 3412-3418, 2005.

[26] Alves MM, Pereira MA, Sousa DZ, et al. "Waste lipids to energy: how to optimize methane production from longchain fatty acids (LCFA)". Microbial biotechnology, 2(5), 538-50, 2009.

[27] Christ O, Wilderer PA, Angerhöfer R, Faulstich M. "Mathematical modeling of the hydrolysis of anaerobic processes". Water Science and Technology, 41(3), 61-65, 2000.

[28] 28. Basak SR, Rouf MA, Hossain MD, Islam MS, Rabeya T. "Anaerobic digestion of tannery solid waste by mixing with different substrates". Bangladesh journal of science and industrial research, 49(2), 119-124, 2014. 